\title{
ALGORITMA GENETIKA DALAM MENENTUKAN RUTE OPTIMAL TOPOLOGI CINCIN PADA WAN
}

\author{
Qilbaaini Effendi Muftikhali ${ }^{1}$, Arnoldus Danar ${ }^{2}$, Aris Kusumawati ${ }^{3}$, Syukron Hidayat ${ }^{4}$ \\ ${ }^{1,2,3,4}$ Fakultas Teknologi Informasi, Institut Teknologi Sepuluh Nopember (ITS) \\ 19ilbaaini.muftikhali@gmail.com, ${ }^{2}$ arnoldusdanar@gmail.com, ${ }^{3}$ kusumawati.aris@gmail.com, \\ ${ }^{4}$ syukronhidayat10@gmail.com
}

(Naskah masuk: 16 Desember 2016, diterima untuk diterbitkan: 23 Maret 2017)

\begin{abstract}
Abstrak
Implementasi jaringan komputer memiliki banyak masalah, terutama pada Wide Area Network (WAN), salah satunya adalah masalah routing. Routing masalah adalah bagaimana melakukan transmisi data antara node dengan jalur tercepat, terutama dalam topologi ring. Dalam topologi ring, setiap simpul hanya bisa dilalui oleh sebanyak satu. Untuk mengatasi masalah ini, kami menggunakan algoritma genetika. Kami telah diuji pada arsitektur wan dari PT. XYZ terletak di Kotawaringin Barat, Kalimantan Tengah. Dengan ukuran populasi 100, metode seleksi elitisme, dan tingkat mutasi 0,08, hasil yang optimal diperoleh dengan jarak akhir adalah 44. Penggunaan metode seleksi elitisme dan nilai rate mutasi sangat berpengaruh untuk mendapatkan rute yang optimal.
\end{abstract}

Kata kunci: Wide Area Network, Routing Problem, Genetic Algorithm, Ring Topology.

\section{Abstract}

The implementation of a computer network has a lot of problems, especially on Wide Area Network (WAN), one of them is a routing problem. Routing problem is how to perform data transmission between nodes with the fastest path, especially in a ring topology. In a ring topology, every node can only be passed by as much as one. To solve this problem, we used a genetic algorithm. We have tested on the wan architecture of PT. XYZ located in Kotawaringin Barat, Central Kalimantan. With a population size of 100, elitism selection method, and the mutation rate of 0.08 , an optimal result is obtained with the final distance is 44 . The use of elitism selection method and mutation rate value is very influential to get the optimal route.

Keywords: Wide Area Network, Routing Problem, Genetic Algorithm, Ring Topology

\section{PENDAHULUAN}

Jaringan komputer yang mendukung informasi dan komunikasi, merupakan dua isu strategis yang paling penting untuk keberhasilan suatu perusahaan. Sebuah jaringan komputer adalah jaringan telekomunikasi yang memungkinkan komputer untuk pertukaran data. Struktur dari jaringan termasuk kelompok sistem komputer dan perangkat komputasi perangkat keras lainnya yang terkait bersama-sama melalui jalur komunikasi. Setiap cabang di jaringan komputer menunjukkan jalur komunikasi dan setiap vertex menunjukkan stasiun transmisi. Bahkan, jalur komunikasi dikombinasikan dengan beberapa jalur fisik, seperti twisted kabel pair, koaksial, dan kabel fiber. Oleh karena itu, jaringan komputer dapat dianggap multinegara (Huang et al., 2016).

Wide Area Network (WAN) merupakan jaringan komputer yang saling berjauhan dan mencakup daerah geografis yang luas, seringkali mencakup sebuah negara atau benua. Dalam melaksanakan koneksinya WAN seringkali menggunakan satelit sebagai media perantara, akan tetapi WAN juga bisa menggunakan koneksi antar router yang biasa disebut dengan point-to-point. Pada subnet point-to-point, masalah rancangan yang penting adalah pemilihan jenis topologi interkoneksi router (www.cisco.com,2004). Pada Gambar 1. menunjukkan beberapa jenis topologi WAN, yaitu : (a) Bintang, (b) Cincin, (c) Pohon, (d) Lengkap, (e) Cincin berinteraksi, dan (f) tidak beraturan.

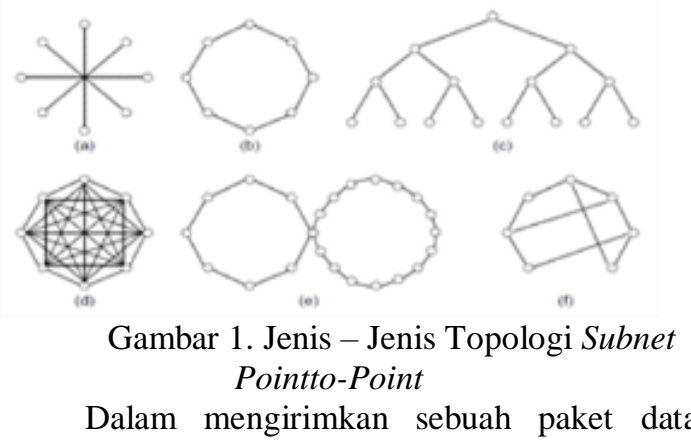
(routing) tentu memerlukan jumlah data yang dikirim, 
besaran, jarak dan kapasitas pengiriman. Setiap data di dalam WAN yang melewati sebuah router dibatasi oleh bandwith yang digunakan. Permasalahan muncul ketika di dalam router itu memiliki kapasitas pengiriman yang berbeda dan waktu yang paling efisien dalam pengiriman data. Permasalahan ini merupakan permasalahn yang sering terjadi dalam implementasi WAN, seperti pada jurnal ini (Huang et al., 2016) mengevaluasi kendala pada jaringan dalam mentransmisikan data dengan hasil jarak terpendek dan waktu tercepat dengan mensimulasikan MCSRN dalam menyelesaikan masalah routing problem.

Permasalahan routing problem selalu ditemukan dalam beberapa topologi jaringan, paper ini membahas routing problem pada topologi cincin (ring) dalam optimasi. Dalam topologi cincin (ring), sebelum menghubungkan antar node, node disini bisa saja berupa router, gateway,dll, langkah pertama yang dilakukan perhitungan hubungan node yang optimal agar terbentuk topologi cincin. Pada awalnya hanya terdapat node-node yang terletak pada tempattempat yang sudah ditetapkan seperti yang terlihat pada Gambar 2. Kemudian terdapat permasalahan routing ,bagaimana menghubungkan node-node tersebut sehingga menjadi topologi cincin yang optimal. Syaratnya adalah satu node hanya boleh dilalui sekali dan semua node harus terhubung.

Sebelum menghubungkan node-node seperti yang terlihat pada Gambar 2, sebaiknya terlebih dahulu membuat perencanaan sehingga bisa meminimalisir travel time. Namun, ketika telah menemukan rute yang optimal, dilakukan pengujian pada rute yang dianggap optimal tersebut.

Dalam proses menemukan rute tersebut merupakan proses yang dianggap sulit, pada gambar yang sama Gambar 2 tetapi hanya terdapat 3 node. Untuk menentukan kemungkinan rute yang dilalui, ada 3 ! = 3x2x1 = 6 kemungkinan rute yang berbeda. Ketika node nya hanya 3 mungkin masih terbilang gampang untuk dihitung, tetapi coba anggap ada 10 titik di peta. Itu berarti ada $10 !=3628800$ kemungkinan rute yang berbeda. Belum lagi jika terdapat 20 node, terdapat 20! Kemungkinan rute yang harus dilalui. Proses yang terjadi memerlukan banyak waktu dan tahapan, kemutahiran teknologi komputer pasti tidak dapat mengatasi itu. Permasalahan dalam routing dapat diselesaikan dengan efisien dengan penerapan algoritma.

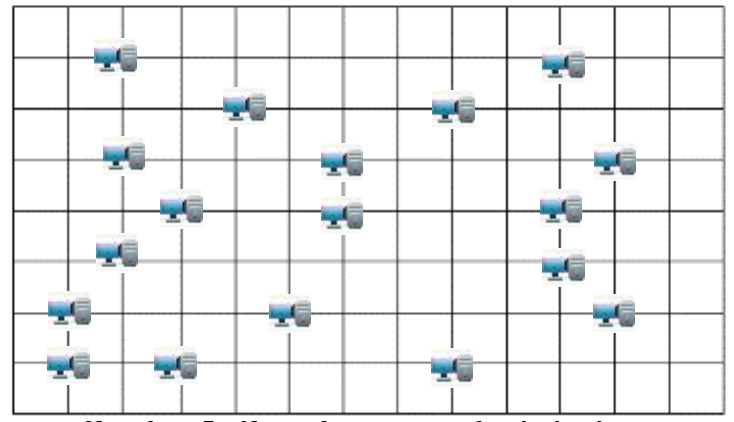

Gambar 2. Contoh peta topologi cincin
Meskipun hal tersebut mungkin tidak praktis untuk menemukan solusi terbaik untuk permasalahan ini, penulis mengusulkan algoritma genetika untuk menyelesaikan masalah ini sehingga mendapatkan solusi rute yang optimum. Algoritma Genetika (AG) merupakan metode evolusi paling banyak digunakan di dunia. Saat itu diperkenalkan oleh Belanda (Holland, 1975) berdasarkan pada seleksi alam dan genetika. Sebuah AG bekerja pada awal populasi, memiliki seorang ayah dan ibu, berlaku crossover dan operator mutasi yang mengevaluasi anak-anak. Tujuannya adalah untuk menghasilkan solusi yang lebih baik secara berurutan dengan memilih yang lebih baik dari solusi yang ada atau lebh sering disebut rekombinasi (Goldberg, 1989). Algoritma genetika telah melalui banyak penerapan dalam berbagai penerannya mendapatkan hasil yang baik dalam beberapa penelitiannya.

Beberapa penelitian terdahulu membahas tentang algoritma genetika diantaranya adalah penyelesaian permasalahan multimedia di mana ketika satu sumber (source) file multimedia diakses oleh beberapa user. Untuk menghemat bandwith yang digunakan peneliti menggunakan algoritma genetika untuk mencari jarak terpendek untuk pengiriman paket data ke dalam dua studi kasus. Studi kasus yang dipakai menggunakan topologi mesh (Hamed, 2010) Algoritma genetika telah melalui banyak penerapan dalam berbagai penerannya mendapatkan hasil yang baik dalam beberapa penelitiannya. Penerapan algoritma genetika dapat menyelesaikan masalah lokasi routing yang dengan beberapa depot berkapasitas dan satu kendaraan berkapasitas per depot. Kami mencari metode baru untuk membuat keputusan lokasi dan routing secara bersamaan dan efisien (Ahmad, 2005). Implementasi algoritma genetika dengan menggunakan mikrokontroler MCS51. Aplikasi yang dipilih untuk percobaan adalah mencari rute terpendek yang menghubungkan suatu tempat asal dan tujuan. Semua proses algoritma genetika seperti membangkitkan populasi awal, evaluasi, seleksi, crossover dan mutasi, dilakukan oleh mikrokontroler MCS51. implementasi algoritma genetika pada mikrokontroler sudah dapat berjalan dengan baik walaupun dengan beberapa batasan antara lain jumlah kromosom per populasi, jenis kromosom binary bit string (Ferdinando, 2001). Algoritma genetika dapat digunakan untuk menyelesaikan masalah optimasi yang kompleks seperti mencari rute paling optimum dengan memperhatikan kondisi jalan misalnya kepadatan lalulintas, jalan satu arah dan lain-lain. Dalam makalah ini akan dijelaskan tentang penerapan algoritma genetika untuk mencari rute yang paling optimum dari titik asal ke titik tujuan. Algoritma genetika cukup efektif dan mudah digunakan khususnya dalam hal mencari rute terpendek dan waktu tersingkat berdasarkan kondisi rute. Algoritma ini menunjukkan keunggulannya pada saat dilakukan perhitungan dengan memakai bobot jarak terhadap 
waktu (Hannawati, 2002). Algoritma genetik adalah pendekatan yang sangat baik untuk memecahkan masalah yang kompleks dalam optimasi dengan kendala yang sulit terutama pada Vehicle Routing Problem (VRP) . Hasil percobaan menunjukkan bahwa algoritma genetika dengan menerapkan Finite Automaton (FA) dalam menghasilkan populasi individu untuk menyelesaikan permasalahan pada Vehicle Routing Problem (VRP) (zhang, 2008)

Menurut penelitian sebelumnya yang memberikan hasil efisien dalam implementasi algoritma genetika. Sehingga dengan permasalahan yang muncul, diusulkan implementasi Genetic Algorithm (GA) yang digunakan untuk mencari rute terpendek dalam proses pengiriman data arsitektur jaringan Wide Area Network (WAN) pada topologi ring.

\section{KAJIAN LITERATUR}

1. Wide Area Network

Wide Area Network (WAN) merupakan jaringan komputer yang saling berjauhan dan mencakup daerah geografis yang luas, seringkali mencakup sebuah negara atau benua. Dalam melaksanakan koneksinya WAN seringkali menggunakan satelit sebagai media perantara, akan tetapi WAN juga bisa menggunakan koneksi antar router yang biasa disebut dengan point-to-point. Pada subnet point-to-point, masalah rancangan yang penting adalah pemilihan jenis topologi interkoneksi router (www.cisco.com, 2004)

\section{Routing Problem}

Permasalahan yang muncul ketika di dalam router itu memiliki kapasitas pengiriman yang berbeda dan waktu yang paling efisien dalam pengiriman data. (Huang et al., 2016)

3. Algoritma Genetika

Algoritma Genetika (AG) merupakan metode evolusi paling banyak digunakan di dunia. Saat itu diperkenalkan oleh Belanda (Holland, 1975) berdasarkan pada seleksi alam dan genetika. Sebuah AG bekerja pada awal populasi, memiliki seorang ayah dan ibu, berlaku crossover dan operator mutasi yang mengevaluasi anak-anak. Tujuannya adalah untuk menghasilkan solusi yang lebih baik secara berurutan dengan memilih yang lebih baik dari solusi yang ada atau lebh sering disebut rekombinasi (Goldberg, 1989)

4. Topologi ring

Topologi jaringan di mana setiap node terhubung ke tepat dua node lain, membentuk jalur terus menerus untuk tiap sinyal melalui setiap node - cincin. Data berjalan dari node ke node, dengan setiap node menangani setiap paket.(Junginger and Lee, 2002)

\section{METODE PENELITIAN}

Untuk menyelesaikan usulan pada makalah ini dilakukan tiga tahapan utama, antara lain :

[1] Membuat design pemetaan node.

Design yang dirancang mengacu pada studi kasus PT.XYZ yang terletak di Kab.Kotawaringin Barat, Kalimantan Tengah. Untuk lebih detail letak dengan peta lokasi PT.XYZ digambarkan pada Gambar 3.

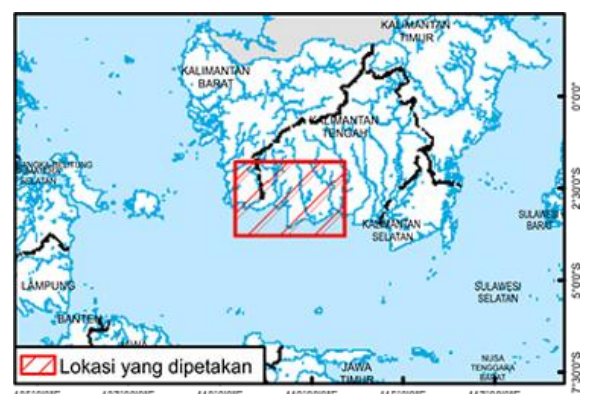

Gambar 3. Studi Kasus Lokasi PT.XYZ

Sedangkan untuk gambaran router yang telah dirancang di PT.XYZ dijelaskan pada Gambar.4. dalam Gambar.5 terdapat arsitektur router dan letak geografis dari router yang telah dibuat. Dari Gambar 4. 22 router telah dibangun di PT.XYZ

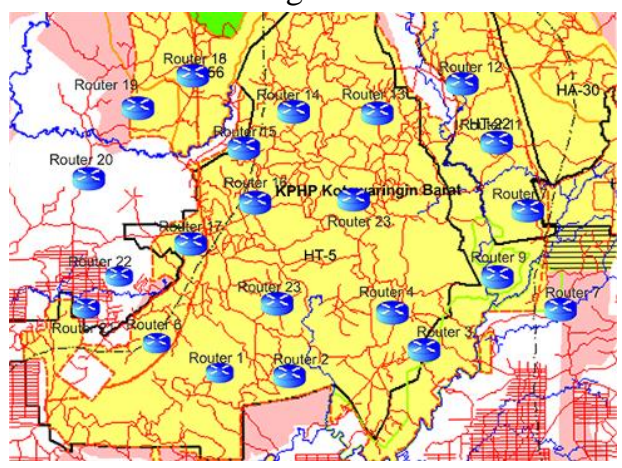

Gambar 4. Desain Peta Node yang akan dioptimasi

Setelah menyusun Router dan sebaran router di wilayah PT.XYZ. Langkah yang ditempuh untuk menyelesaikan routing protokol yang memiliki jarak terpendek, selanjutnya memetakan seluruh node yang telah terbentuk tersebut ke dalam diagram Cartesian yang telah diterangkan pada Gambar 5. 


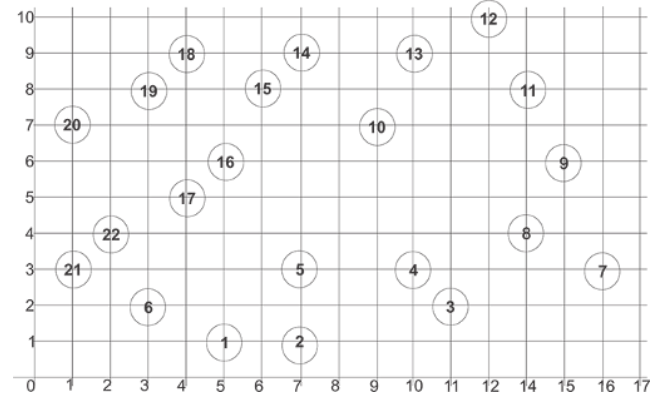

Gambar 5. Desain Peta Lokasi Node dalam Bentuk Kartesian

Gambar.5 menunjukkan sebaran node yang sudah dibuat, untuk menghitung jarak antar node digunakan algoritma genetika dengan asumsi bahwa hanya satu kali saja lewat melalui node. Untuk perhitungan detail nya akan di bahas pada bab selanjutnya.

[2] Memformulasikan Algoritma Genetika : Algoritma genetika merupakan suatu metode pencarian yang didasarkan pada mekanisme dari seleksi dan genetika natural. Secara umum menurut (Hannawati, 2002), blok diagram dari mekanisme kerja algoritma genetika ini adalah seperti yang terlihat pada Gambar 6.

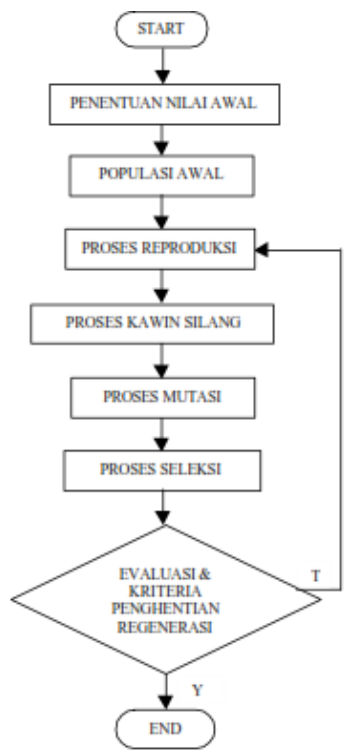

Gambar 6. Diagram Alir Algoritma Genetika

\section{Keterangan :}

Dalam menyelesaikan suatu permasalahan, algoritma genetika diawali dengan menginisialisasikan himpunan solusi yang dibangkitkan secara acak (random). Himpunan solusi ini disebut populasi (Population). Setiap individu pada populasi disebut kromosom (Chromosom), yang menggambarkan sebuah solusi dari suatu masalah yang akan diselesaikan. Sebuah kromosom dapat dinyatakan dalam simbol string, misalnya kumpulan string bit atau string kemungkinan rute. Dalam sebuah populasi, setiap kromosom akan dievaluasi dengan menggunakan alat ukur yang disebut dengan fitness (tingkat kesesuaian). Nilai fitness ini digunakan untuk mencari dua kromosom (yang memiliki nilai fitness yang sesuai) dari sebuah populasi yang akan dijadikan sebagai kromosom induk untuk melakukan regenerasi. Kromosom induk ini akan melakukan regenerasi melalui pindah silang (crossover) dan melakukan mutasi (mutation) yang akan menghasilkan kromosom baru (offspring). Pindah silang (crossover) dilakukan dengan cara menggabungkan dua kromosom induk dengan menggunakan operator pindah silang (crossover). Sedangkan mutasi hanya berlaku pada sebuah kromosom, dan kromosom ini akan mengalami suatu perubahan (misalnya : 11101100 menjadi 11001100 pada string bit). Hasil dari pindah silang dan mutasi ini (offspring) akan di evaluasi dengan menggunakan alat ukur yang disebut fitness (tingkat kesesuaian). Kemudian akan dilihat apakah offspring ini merupakan solusi yang optimal atau belum. Jika optimal maka offspring ini lah jawabannya. Jika tidak, maka offspring ini akan diseleksi (selection) lagi dengan menggunakan salah satu metode seleksi. Offspring yang lulus seleksi akan menjadi populasi yang baru dan akan melakukan regenerasi lagi, sedangkan yang tidak lulus seleksi akan dibuang. Regenerasi akan berhenti jika jumlah iterasi telah terpenuhi dan ditemukannya solusi optimal dari permasalahan yang diselesaikan.

[3] Desain program untuk algoritma genetika pada permasalahan rute optimal pada topologi cincin.

Bahasa pemrograman yang akan digunakan untuk mencari hasil yang optimal pada 
permasalahan ini adalah Java. Terdapat 5

class yang akan dirancang :

a. Class Node

Untuk mengatur lokasi node inputan

dan jarak antar node.

b. Class Population

Untuk mengatur populasi atau

\begin{tabular}{|l|l|l|l|l|l|l|l|l|}
\hline 1 & 2 & 3 & 4 & 5 & 6 & 7 & 8 & 9 \\
\hline
\end{tabular}

kromosom dari kandidat-kandidat rute.

c. Class Tour

\begin{tabular}{|l|l|l|l|l|l|l|l|l|}
\hline 1 & 2 & 3 & 4 & 5 & 6 & 7 & 8 & 9 \\
\hline
\end{tabular}

Untuk enkode rute-rute hubungan antar node.

d. Class TourManager

Untuk mengatur seluruh node tujuan untuk rute yang akan ditentukan.

e. Class GA

Untuk menangani kerja dari algoritma genetika dan menyusun solusi dari populasi

\section{EKSPERIMENT DAN HASIL}

\subsection{Perumusan Algoritma Genetika}

\begin{tabular}{|l|l|l|l|l|l|l|l|l|}
\hline 1 & 2 & 3 & 4 & 5 & 6 & 7 & 8 & 9 \\
\hline
\end{tabular}
\begin{tabular}{|l|l|l|l|l|l|l|l|l|}
\hline Algoritma genetika yang digunakan \\
9 & 8 & 7 & 6 & 5 & 4 & 3 & 2 & 1 \\
\hline
\end{tabular}

memiliki karakteristik sebagai berikut :

1. Representai kromosom yang digunakan

\begin{tabular}{|l|l|l|l|l|l|l|l|l|}
\hline & & & & & 6 & 7 & 8 & \\
\hline 9 & 5 & 4 & 3 & 2 & 6 & 7 & 8 & 1 \\
\hline
\end{tabular}

adalah permutasi dari node-node tujuan.

Sebagai contoh, apabila node-node tujuan adalah $n_{1}, n_{2}, n_{3}, n_{4}, n_{5}$, maka salah satu kromosom yang dapat digunakan adalah $n_{3}, n_{5}, n_{1}, n_{2}, n_{4}$. Hal ini menunjukkan bahwa rute yang terbentuk adalah $n_{3} \rightarrow n_{5} \rightarrow n_{1} \rightarrow$ $n_{2} \rightarrow n_{4}$.

2. Besar populasi yang digunakan adalah 50 .

3. Fungsi fitness yang digunakan adalah

$$
\sum_{i=1}^{m} \sqrt{\left(x_{i}-x_{i-1}\right)^{2}+\left(y_{i}-y_{i-1}\right)^{2}}
$$

dimana $x_{i}$ dan $y_{i}$ adalah absis dan ordinat dari node tujuan ke- $i$.

4. Metode seleksi yang digunakan adalah metode elitism.
Metode seleksi elitism memilih kromosomkromosom untuk dipakai pada generasi selanjutnya didasarkan pada urutan nilai fitness. Semakin baik nilai fitnessnya maka kromosom tersebut akan dipertahankan (Wati, 2011).

5. Operator mutasi yang digunakan adalah swap mutation.

Dengan swap mutation 2 node dalam rute dipilih secara acak, kemudian posisinya ditukar. Sebagai contoh, jika kita terapkan swap mutation pada list berikut, [1,2,3,4,5], kemungkinan hasil swap yang didapat adalah $[1,2,5,4,3]$. Disini posisi 3 dan 5 ditukar sehingga membuat list yang dengan nilai-nilai yang persis sama, hanya berbeda urutan. Karena swap mutation hanya menukar nilai yang sudah ada, maka tidak akan terjadi pembuatan list yang mempunyai nilai yang hilang atau ganda ketika dibandingkan dengan yang asli.

6. Operator crossover (kawin silang) yang digunakan adalah crossover terurut. Dalam metode ini dipilih subset dari parent pertama, dan kemudian subset tersebut ditambahkan ke offspring. Jika ada nilai yang hilang maka kemudian ditambahkan ke offspring dari parent kedua dengan urutan ketika ditemukan. Sebagai contoh :

\section{Parents}

\section{Offspring}

Disini subset dari rute diambil dari parent pertama $(6,7,8)$ dan kemudian ditambahkan ke rute offspring. Berikutnya, lokasi rute yang hilang ditambahkan dalam urutan dari parent kedua. Node pertama dari rute parent kedua adalah 9 yang mana tidak terdapat pada rute offspring jadi ditambahkan di posisi pertama yang tersedia. Posisi berikutnya pada rute parent adalah 8 yang mana terdapat di rute offspring maka dilewatkan. Proses ini dilanjutkan hingga offspring tidak mempunyai nilai yang kosong lagi.

7. Kondisi pemberhentian yang digunakan adalah ketika banyaknya generasi telah mencapai 1000. 


\subsection{Pengujian Sistem}

Pengujian proses algoritma genetika dilakukan dengan melakukan perubahan nilai parameter yang digunakan, yaitu nilai mutation rate, jumlah kromosom perpopulasi serta pengunaan metode seleksi elitism atau tidak. Bentuk rute pengujian dapat dilihat pada Gambar 5. Pengujian yang dilakukan adalah mencari rute paling optimum. Rute paling optimum didapat dengan nilai final distance terkecil. Secara ringkas, hasil pengujian dapat dilihat pada Tabel 1.

Tabel 1. Hasil Pengujian

\begin{tabular}{|c|c|c|c|c|c|}
\hline $\begin{array}{l}\mathrm{Ju} \\
\mathrm{m} \\
\mathrm{la} \\
\mathrm{h} \\
\mathrm{K} \\
\mathrm{ro} \\
\mathrm{m} \\
\mathrm{o} \\
\mathrm{so} \\
\mathrm{m}\end{array}$ & $\begin{array}{l}E l \\
i \\
t i s \\
m\end{array}$ & $\begin{array}{l}\text { M } \\
\text { ut } \\
a \\
\text { tio } \\
n \\
\text { Ra } \\
\text { te }\end{array}$ & $\begin{array}{l}\text { Ini } \\
\text { tia } \\
l \\
\text { Di } \\
\text { s } \\
\text { tan } \\
\text { ce }\end{array}$ & $\begin{array}{l}\text { Fi } \\
n a \\
l \\
D i \\
s \\
\text { ta } \\
n c \\
e\end{array}$ & Rute \\
\hline $\begin{array}{l}1 \\
0\end{array}$ & $\begin{array}{l}t r \\
u e\end{array}$ & $\begin{array}{l}0 . \\
08\end{array}$ & $\begin{array}{l}11 \\
2\end{array}$ & 44 & $\begin{array}{l}(8) \rightarrow(7) \rightarrow(9) \rightarrow(11) \rightarrow \\
(12) \rightarrow(13) \rightarrow(10) \rightarrow \\
(14) \rightarrow(15) \rightarrow(18) \rightarrow(2 \\
0) \rightarrow(19) \rightarrow(16) \rightarrow \\
(17) \rightarrow(22) \rightarrow(21) \rightarrow(6) \\
\rightarrow(1) \rightarrow(2) \rightarrow \\
(5) \rightarrow(4) \rightarrow(3)\end{array}$ \\
\hline & $\begin{array}{l}f a \\
l s \\
e\end{array}$ & & $\begin{array}{l}10 \\
7\end{array}$ & 53 & $\begin{array}{l}(13) \rightarrow(12) \rightarrow(10) \rightarrow(1 \\
4) \rightarrow(15) \rightarrow(19) \rightarrow \\
(18) \rightarrow(16) \rightarrow(17) \rightarrow(2 \\
1) \rightarrow(22) \rightarrow(20) \rightarrow \\
(6) \rightarrow(1) \rightarrow(5) \rightarrow(2) \rightarrow( \\
4) \rightarrow(3) \rightarrow(8) \rightarrow \\
(7) \rightarrow(9) \rightarrow(11)\end{array}$ \\
\hline & $\begin{array}{l}\text { tr } \\
\text { ue }\end{array}$ & $\begin{array}{l}0 . \\
2\end{array}$ & $\begin{array}{l}10 \\
6\end{array}$ & 63 & $\begin{array}{l}(14) \rightarrow(15) \rightarrow(10) \rightarrow(1 \\
2) \rightarrow(11) \rightarrow(9) \rightarrow \\
(7) \rightarrow(8) \rightarrow(4) \rightarrow(3) \rightarrow( \\
2) \rightarrow(17) \rightarrow(19) \rightarrow \\
(16) \rightarrow(13) \rightarrow(5) \rightarrow(1) \\
\rightarrow(6) \rightarrow(21) \rightarrow \\
(22) \rightarrow(20) \rightarrow(18)\end{array}$ \\
\hline & $\begin{array}{l}f a \\
l s \\
e\end{array}$ & & $\begin{array}{l}11 \\
5\end{array}$ & $\begin{array}{l}10 \\
5\end{array}$ & $\begin{array}{l}(5) \rightarrow(15) \rightarrow(12) \rightarrow(13) \\
\rightarrow(8) \rightarrow(10) \rightarrow \\
(2) \rightarrow(14) \rightarrow(9) \rightarrow(11) \\
\rightarrow(7) \rightarrow(18) \rightarrow \\
(6) \rightarrow(16) \rightarrow(19) \rightarrow(20) \\
\rightarrow(22) \rightarrow \\
(21) \rightarrow(1) \rightarrow(3) \rightarrow(4) \rightarrow \\
(17)\end{array}$ \\
\hline $\begin{array}{l}2 \\
2 \\
0\end{array}$ & $\begin{array}{l}\text { tr } \\
\text { ue }\end{array}$ & $\begin{array}{l}0 . \\
08\end{array}$ & $\begin{array}{l}10 \\
1\end{array}$ & 44 & $\begin{array}{l}(11) \rightarrow(12) \rightarrow(13) \rightarrow(1 \\
0) \rightarrow(14) \rightarrow \\
(15) \rightarrow(18) \rightarrow(19) \rightarrow(1 \\
6) \rightarrow(17) \rightarrow \\
(20) \rightarrow(22) \rightarrow(21) \rightarrow(6)\end{array}$ \\
\hline
\end{tabular}

\begin{tabular}{|c|c|c|c|c|}
\hline & & & & $\begin{array}{l}\rightarrow(1) \rightarrow \\
(2) \rightarrow(5) \rightarrow(4) \rightarrow(3) \rightarrow( \\
8) \rightarrow(7) \rightarrow(9)\end{array}$ \\
\hline $\begin{array}{l}f a \\
l s \\
e\end{array}$ & & $\begin{array}{l}11 \\
4\end{array}$ & 52 & $\begin{array}{l}(5) \rightarrow(1) \rightarrow(2) \rightarrow(6) \rightarrow( \\
22) \rightarrow(17) \rightarrow \\
(21) \rightarrow(20) \rightarrow(18) \rightarrow(1 \\
9) \rightarrow(16) \rightarrow \\
(14) \rightarrow(15) \rightarrow(10) \rightarrow(1 \\
3) \rightarrow(12) \rightarrow \\
(11) \rightarrow(9) \rightarrow(7) \rightarrow(8) \rightarrow \\
(3) \rightarrow(4)\end{array}$ \\
\hline $\begin{array}{l}\text { tr } \\
\text { ue }\end{array}$ & $\begin{array}{l}0 . \\
2\end{array}$ & $\begin{array}{l}11 \\
6\end{array}$ & 62 & $\begin{array}{l}(1) \rightarrow(6) \rightarrow(22) \rightarrow(21) \\
\rightarrow(17) \rightarrow(19) \rightarrow \\
(18) \rightarrow(14) \rightarrow(12) \rightarrow(1 \\
3) \rightarrow(16) \rightarrow \\
(20) \rightarrow(15) \rightarrow(10) \rightarrow(1 \\
1) \rightarrow(9) \rightarrow \\
(7) \rightarrow(8) \rightarrow(3) \rightarrow(4) \rightarrow( \\
2) \rightarrow(5)\end{array}$ \\
\hline $\begin{array}{l}f a \\
l s \\
e\end{array}$ & & $\begin{array}{l}11 \\
6\end{array}$ & $\begin{array}{l}10 \\
6\end{array}$ & $\begin{array}{l}(7) \rightarrow(5) \rightarrow(15) \rightarrow(21) \\
\rightarrow(6) \rightarrow(16) \rightarrow \\
(19) \rightarrow(18) \rightarrow(4) \rightarrow(20) \\
\rightarrow(12) \rightarrow \\
(10) \rightarrow(14) \rightarrow(17) \rightarrow \rightarrow \\
(1) \rightarrow(2) \rightarrow \\
(22) \rightarrow(3) \rightarrow(13) \rightarrow(11) \\
\rightarrow(9) \rightarrow(8)\end{array}$ \\
\hline
\end{tabular}

Dari hasil pengujian didapatkan bahwa jumlah kromosom tidak berpengaruh signifikan terhadap hasil yang didapat. Hasil rute paling optimal dari pengujian adalah dengan final distance 44 yang didapat dari pengujian dengan jumlah kromosom perpopulasi adalah 100 dan 220, elitism true dan Mutation rate 0.08 . Meskipun didapat rute dengan jarak optimal yang sama, tetapi menghasilkan rute yang berbeda seperti yang terlihat pada Gambar 6 dan Gambar 7. Hal ini dikarenakan jumlah kromosom perpopulasi yang berbeda. Tetapi keduanya dapat dikatakan rute yang paling optimal. Rute paling jauh didapat dari kombinasi jumlah kromosom 220, elitism false dan mutation rate 0.2 dengan final distance 106. Rute yang didapat dapat dikatakan "tidak teratur" seperti yang terlihat pada Gambar 8 dibandingkan dengan Gambar 6 dan Gambar 7. Hal ini dikarenakan metode seleksi elitism tidak diterapkan sehingga kromosom-kromosom yang memiliki nilai fitness terbaik tidak dipertahankan sehingga meningkatkan kemungkinan untuk mendapatkan kromosom yang kurang baik.

Seperti yang terlihat pada Tabel 1, penggunaan metode seleksi elitism sangat berpengaruh terhadap hasil. Dari hasil pengujian didapatkan bahwa pengujian dengan menggunakan elitism akan menghasilkan hasil yang lebih bagus dibandingkan dengan tidak menggunakan elitism. Metode seleksi elitism memilih kromosom-kromosom untuk dipakai 
pada generasi selanjutnya didasarkan pada urutan nilai fitness. Semakin baik nilai fitnessnya maka kromosom tersebut akan dipertahankan [11]. Oleh karena itu, hasil yang didapat lebih optimal. Dari tabel 1 juga dapat dilihat bahwa nilai mutation rate 0.08 lebih menghasilkan hasil yang lebih baik daripada nilai mutation rate 0.2 .

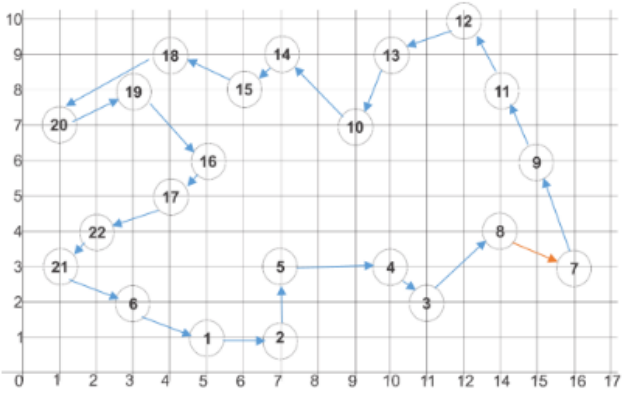

Gambar 6. Final Distance 44 (Jumlah Kromosom 100)

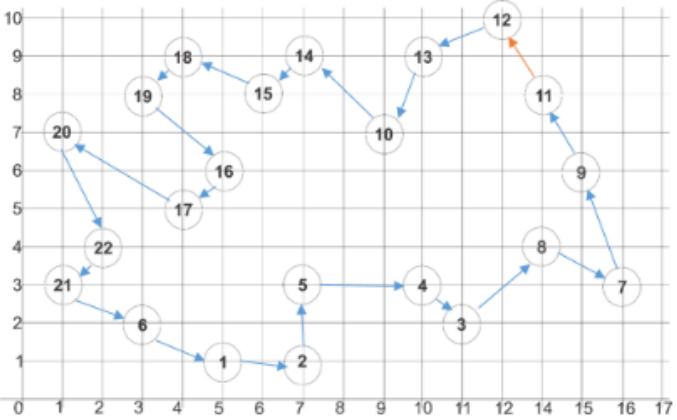

Gambar 7. Final Distance 44 (Jumlah Kromosom 220)

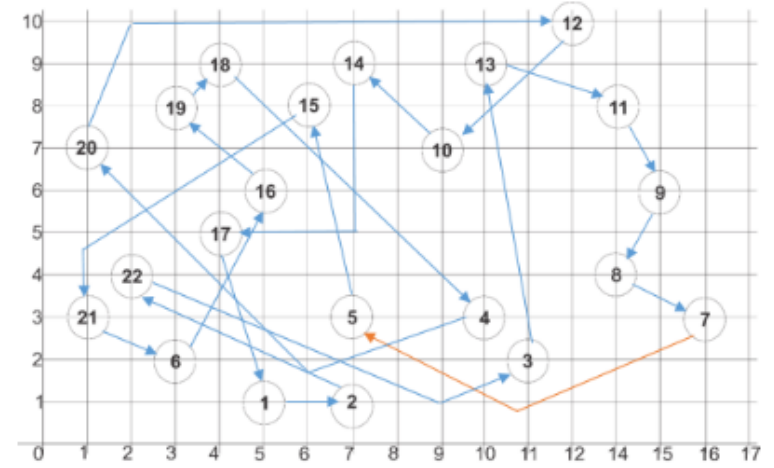

Gambar 8. Final Distance 106

\section{KESIMPULAN DAN SARAN}

Kesimpulan yang dapat diambil dari penelitian ini adalah dengan menggunkaan jumlah populasi yang tepat, metode seleksi elitism dan mutation rate yang tepat, algoritma genetika dapat dapat diimplementasikan dalam permasalahan penentuan rute optimal pada topologi cincin. Penggunaan metode seleksi elitism dan nilai mutation rate sangat berpengaruh untuk mendapatkan rute yang optimal. Kombinasi penggunaan elitism dan nilai mutation rate 0.08 mendapatkan hasil paling optimal. Dengan panjang rute yang sama juga dapat menghasilkan gambar rute yang berbeda seperti yang terlihat pada Gambar 6 dan Gambar 7.

\section{REFERENSI}

AHMED, Z.H. 2005. "Genetic Algorithm for Travelling Salesman Problem using Sequential Constructive Crossover Operator". International Journal of Biometrics \& Bioinformatics 3, 96-105.

CISCO. 2004. "Cisco System Inc". 2004. www.Cisco.com/en/US humpgs.

FERDINANDO , HANY ,THIANG, RONALD KURNIAWAN. 2001. "Implementasi Algoritma Genetika pada Mikrokontroler MCS51 Untuk Mencari Rute Terpendek". Proceeding, Seminar of Intelligent Technology and Its Applications (SITIA 2001) Institut Teknologi Sepuluh Nopember.

GOLDBERG DE . 1989. Genetic algorithms in search optimization and machine learning. Reading , Massachusetts : Addison Wesley.

HANNAWATI ,ANIES.THIANG, ELEAZAR. 2002. "Pencarian Rute Optimum Menggunakan Algoritma Genetika". Jurnal Teknik Elektro Fakultas Teknologi Industri - Universitas Kristen Petra Vol. 2, No. 2, 78 $-83$.

HANNAWATI. 2002 A. dkk.Pencarian Rute Optimum Menggunakan Algoritma Genetika. Jurnal Teknik Elektro Volume 2.

HAMED A. Y. 2010. "A genetic algorithm for finding the $\mathrm{k}$ shortest paths in a network," Egypt. Informatics J., vol. 11, no. 2, pp. 7579, Dec.

HOLLAND HJ .1975. Adaptation in natural and artificial systems. Ann Arbor : University of Michigan Press.

HUANG, C.-F., LIN, Y.-K., YENG, L.C.-L., 2016. Routing scheme of a multi-state computer network employing a retransmission mechanism within a time threshold. Inf. Sci. 340-341, 321-336. doi:10.1016/j.ins.2016.01.027.

JUNGINGER, M., LEE, Y., 2002. The multi-ring topology-high-performance group communication in peer-to-peer networks. Presented at the Peer-to-Peer Computing, 2002.(P2P 2002). Proceedings. Second International Conference on, IEEE, pp. 4956.

ZHANG ,YUEQIN, JINFENG LIU, FU DUAN \& JING REN. 2008. "Genetic Algorithm in Vehicle Routing Problem". Institute of Computer and Software, Taiyuan University of Technology, Taiyuan, Shanxi, China, 030024 